\title{
STRATEGI PENINGKATAN EFISIENSI BIAYA PADA BANK UMUM SYARIAH BERBASIS STOCHASTIC FRONTIER APPROACH DAN DATA ENVELOPMENT ANALYSIS
}

\author{
Rafika Rahmawati
}

\begin{abstract}
Entering the ASEAN Economic Community (AEC) in 2015, the Islamic banking in Indonesia is expected to have better performance to compete sustainably with local banks and foreign. The performance of the banks using the cost efficiency approach with a focus on two inputs (cost of fund and cost of labor) and the two outputs (total financing and owned securities). Using Stochastic Frontier Approach (SFA) and Data Envelopment Analysis (DEA) on Islamic Banks during the period of January 2010 to December 2013, the result shows that the level of efficiency of the Islamic banks in Indonesia is not optimal. Our calculation shows different result for both method (SFA and DEA), where the highest efficiency levels using SFA method is Bank Mega Syariah, while with the DEA method is Bank Muamalat Indonesia. Leaving some option of strategies to improve their cost efficiency; this includes increasing their assets, increasing deposits, and cut cost the unnecessarily cost. More strategy includes product innovation, reducing the salary of the board of directors, and put the funds in profitable portfolio. For the authorities, this paper has demonstrated the use of frontier approach as good alternative in assessing the performance of the banks.
\end{abstract}

Keywords: cost efficiency, Islamic banks, SFA, DEA.

JEL Classification: G2, C1, C3

1 Author is a student at Postgraduate Program in Management Science. Institut Pertanian Bogor; fika_annaliez@yahoo.co.id. 


\section{PENDAHULUAN}

Periode Masyarakat Ekonomi ASEAN (MEA) akan segera direalisasikan pada tahun 2015. Hal tersebut akan menjadi periode yang berat bagi bank syariah di Indonesia. Ditambah dengan adanya integrasi jasa keuangan ASEAN pada tahun 2020, maka perbankan asing akan membanjiri Indonesia. Bank lokal, khususnya bank syariah tentunya akan kesulitan bersaing dengan bank-bank asing. Hal tersebut disebabkan bank asing mampu menawarkan bunga kredit yang lebih kecil dibandingkan bank lokal.

Pada UU Nomor 21 Tahun 2008 Tentang Perbankan Syariah disebutkan bahwa terdapat tiga bentuk perbankan syariah di Indonesia, yaitu Bank Umum Syariah (BUS), Unit Usaha Syariah (UUS), dan Bank Pembiayaan Rakyat Syariah (BPRS). Perkembangan bank syariah di Indonesia masih belum optimal, baik dari segi jumlah bank, jumlah kantor, maupun jumlah asetnya. Pada Outlook Perbankan Syariah 2014 tercatat pertumbuhan aset Bank Umum Syariah dan Unit Usaha Syariah per Oktober 2013 (yoy) 31,8\% atau mengalami perlambatan pertumbuhan dibandingkan tahun 2012 yaitu sebesar 34,1\%. Dari posisi deposit account sebanyak 12,3 juta (9,2\% dari nasional). Selain itu, market share perbankan syariah terhadap perbankan nasional saat ini telah mencapai 4,8\%. Market share perbankan syariah tersebut masih sangat kecil.

Dibandingkan dengan Bank Umum Konvensional (BUK), perkembangan Bank Umum Syariah masih sangat kecil. Dari sisi jumlah, hanya ada 11 BUS diantara 124 BUK. Selain itu, ratarata tingkat pertumbuhan jumlah DPK (Dana Pihak Ketiga) BUK sebesar 15,94\% selama 5 tahun terakhir, sedangkan BUS sebesar 35,6\%. Dari sisi pertumbuhan DPK, BUS memang mengalami pertumbuhan yang lebih besar. Namun, dari segi jumlah DPK, BUK masih lebih besar.

Hal lainnya yaitu perbedaan antara BUK dan BUS dalam tingkat suku bunga atau bagi hasil yang diperuntukkan bagi nasabah. Diketahui bahwa tingkat suku bunga rata-rata DPK untuk tabungan pada BUK lebih kecil yaitu 2,01\% dibandingkan tingkat bagi hasil pada BUS yaitu sebesar $5,66 \%$. Hal tersebut mengakibatkan banyak masyarakat yang lebih memilih menyimpan dananya di BUS. Sedangkan tingkat suku bunga rata-rata kredit untuk modal kerja pada BUK sebesar 12,14\% lebih kecil dari margin rata-rata pembiayaan untuk modal kerja pada BUS yaitu sebesar $14,33 \%$. Hal ini akan membuat masyarakat lebih memilih untuk meminjam dana di BUK. Dengan demikian BUS akan terbebani dengan menumpuknya DPK yang juga akan menambah besar kewajiban BUS untuk membayar bagi hasil. Namun, sumber pendapatan bank terbesar yaitu dari kredit/pembiayaan, masih kecil yang diperoleh BUS.

Oleh karena itu, BUS harus mampu mengelola dana dengan efisien agar dapat bersaing dengan BUK. Dengan efisiennya BUS, maka BUS akan dapat memberikan persentase fee atau margin yang lebih kecil bagi para peminjam dana di BUS, sehingga ini menjadi daya tarik utama bagi nasabah yang ingin meminjam dana di BUS. Dengan pengelolaan dana yang efisien, BUS akan dapat bersaing. Dengan demikian market share bank syariah dapat meningkat. 
Selama ini kinerja bank diukur menggunakan standar akuntansi atau rasio-rasio keuangan, misalnya dari return on equity $(R O E)$, return on asset $(R O A)$, asset turn over maupun return on permanent capital. Namun, dengan mengukur efisiensi dari standar akuntansi, sumbersumber inefisiensi pada manajerial perbankan dan faktor-faktor eksternal dan internal yang mempengaruhi terjadinya inefisiensi pada bank tidak dapat diketahui (Sutawijaya dan Lestari, 2009).

Dalam mengukur tingkat efisiensi, terdapat 2 pendekatan. Pertama, melalui pendekatan parametric diantaranya Stochastic Frontier Approach (SFA), Thick Frontier Approach (TFA), dan Distribution Free Approach (DFA). Pendekatan kedua, melalui pendekatan non parametric diantaranya Data Envelopment Analysis (DEA) dan Free Disposable Hull.

Pada paper ini akan dilakukan analisis tingkat efisiensi biaya dengan menggunakan pendekatan parametrik yaitu Stochastic Frontier Approach (SFA) dan pendekatan non parametrik yaitu Data Envelopment Analysis (DEA), serta menganalisis faktor-faktor yang mempengaruhi efisiensi biaya pada BUS. Selain itu, paper ini juga akan menganalisis strategi-strategi dalam peningkatan efisiensi biaya pada BUS di Indonesia sebagai bentuk implementasi dari hasil pengukuran tingkat efisiensi menggunakan metode Stochastic Frontier Approach.

Bagian kedua dari paper ini menguraikan teori efisiensi dan penelitian-penelitian yang telah dilakukan sebelumnya. Kemudian pada Bagian ketiga menyajikan metodologi dan data yang digunakan dalam paper ini. Bagian keempat menjelaskan hasil perhitungan dan analisisnya, sementara bagian kelima menyajikan kesimpulan dan menjadi penutup.

\section{TEORI}

Penelitian mengenai efisiensi khususnya dengan pendekatan frontier pada perbankan dimulai oleh Sherman dan Gold (1985). Mereka mengaplikasikan pendekatan frontier pada industri perbankan dengan fokus pada pengukuran efisiensi operasional simpan pinjam bank. Sejak saat itu, banyak penelitian-penelitian yang menggunakan pendekatan frontier untuk mengukur efisiensi perbankan (Hanim, et all. 2006).

Pengukuran tingkat efisiensi dengan pendekatan frontier dibedakan menjadi dua, yaitu pertama, deterministic approach yang biasa disebut pedekatan non parametrik, pendekatan ini mengunakan Technical Mathematic Programing, atau populer dengan Data Envelopment Analysis/DEA). Kedua, Stochastic Approach, pendekatan ini digolongkan sebagai pendekatan parametrik, menggunakan Econometric Frontier.

Hadad, dkk (2003) mengukur tingkat efisiensi dengan pendekatan parametrik yaitu dengan metode Stochastic Frontier Approach (SFA) dan metode Distribution Free Approach (DFA). Diketahui bahwa bank-bank yang paling efisien yang dihasilkan dengan menggunakan kedua metode adalah sama. Namun, skor efisiensi DFA lebih beragam dibandingkan dengan 
skor efisiensi SFA, jika digunakan data bulanan dan data tahunan yang menggabungkan seluruh bank.

Mokhtar, dkk (2006) mengukur tingkat efisiensi teknis dan efisiensi biaya bank syariah di Malaysia dengan metode SFA. Dalam mengukur efisiensi teknis, input yang digunakan yaitu total simpanan dan total biaya, sedangkan output yang digunakan yaitu total aktiva produktif. Dalam mengukur efisiensi biaya, variabel ditambah dengan harga tenaga kerja dan modal fisik, serta harga dari deposito. Hasilnya menunjukan bahwa rata-rata efisiensi teknis dan biaya bank umum konvensional lebih tinggi dari bank syariah.

Pada pengukuran tingkat efisiensi model DEA terdapat 2 model yang digunakan dalam menganalisis efisiensi suatu Unit Kegiatan Ekonomi (UKE). Pertama, model dengan asumsi constant return to scale (CRS) atau biasa disebut model CCR (Charnes-Cooper-Rhodes). Dalam model constant return to scale setiap UKE akan dibandingkan dengan seluruh UKE yang ada di sampel dengan asumsi bahwa kondisi internal dan eksternal UKE adalah sama. Menurut Charnes, Cooper, dan Rhodes model ini dapat menunjukkan technical efficiency secara keseluruhan atau nilai dari profit efficiency untuk setiap UKE.

Sedangkan model kedua yaitu variable return to scale (VRS) atau biasa disebut dengan model BCC (Bankers-Charnes-Cooper). Dalam model ini diasumsikan bahwa kondisi semua UKE tidak sama atau dapat dikatakan bahwa tidak semua UKE beroperasi secara optimal. Persaingan tidak sempurna, kendala keuangan dan sebagainya mungkin menyebabkan sebuah perusahaan tidak beroperasi pada skala yang optimal.

Penelitian oleh Firdaus dan Hosen (2012) tentang pengukuran tingkat efisiensi BUS dengan metode DEA menggunakan asumsi constant return to scale (CRS) menunjukkan bahwa secara keseluruhan tingkat efisiensi BUS di Indonesia selama periode penelitian belum mencapai tingkat efisiensi yang optimal.

Pada paper ini akan dianalisis perhitungan efisiensi biaya dengan dua metode. Pertama, metode SFA. Kedua, metode DEA dengan asumsi constant return to scale (CRS). Kemudian dilakukan analisis faktor-faktor input dan output mana yang berpengaruh terhadap efisiensi biaya pada masing-masing BUS.

\section{METODOLOGI}

\subsection{Data dan Variabel}

Data yang digunakan adalah data sekunder, yaitu data yang diperoleh dari informasi yang dipublikasikan oleh Bank Indonesia pada Januari 2010 sampai Desember 2013. Metode pengumpulan data ini berupa dokumentasi, yaitu metode pengumpulan data yang dibutuhkan dalam penelitian ini diperoleh dari berbagai media baik cetak maupun elektronik. 
Populasi yang dijadikan objek penelitian adalah seluruh bank yang beroperasi berdasarkan prinsip syariah yang tercatat selama periode tahun 2010 sampai 2013 sejumlah 2.990 bank dengan rincian 11 Bank Umum Syariah, 23 Unit Usaha Syariah, dan 163 Bank Pembiayaan Rakyat Syariah. Teknik pengambilan sampel dilakukan secara purposive sampling dengan kriteria Bank Umum Syariah (BUS) yang beroperasi dan terdapat laporan keuangan bulanan secara lengkap selama periode Januari 2010 sampai Desember 2013. Berdasarkan kriteria tersebut, maka yang menjadi sampel dalam penelitian ini adalah 5 BUS, yaitu Bank Muamalat Indonesia, Bank Syariah Mandiri, Bank Mega Syariah, BRI Syariah, dan Bank Syariah Bukopin

Penentuan input dan output dilakukan dengan pendekatan asset approach seperti yang digunakan oleh Muliaman D. Hadad dalam penelitiannya. Input yang digunakan yaitu Beban Personalia dan Beban Bagi Hasil, sedangkan output yang digunakan yaitu Total Pembiayaan dan Surat Berharga yang Dimiliki. Berikut definisi operasional variabel dapat diringkas pada variabel berikut.

\begin{tabular}{|c|c|c|c|}
\hline \multicolumn{4}{|c|}{$\begin{array}{c}\text { Tabel } 1 . \\
\text { Operasional Variabel-Variabel Penelitian }\end{array}$} \\
\hline Jenis Variabel & Indikator & Definisi Indikator & Skala \\
\hline Dependen & Total Biaya (TC) & $\begin{array}{l}\text { Penjumlahan dari Beban estimasi kerugian komitmen dan kontinjensi + Total } \\
\text { beban operasional lainnya + Beban penyisihan penghapusan aktiva + Beban } \\
\text { non operasional). }\end{array}$ & Jutaan Rupiah \\
\hline Independen & $\begin{array}{l}\text { Beban Personalia } \\
\left(\mathrm{P}_{1}\right)\end{array}$ & Salah satu beban operasional bank, yang pencatatannya pada laba rugi. & Jutaan Rupiah \\
\hline Independen & $\begin{array}{l}\text { Beban Bagi Hasil } \\
\left(\mathrm{P}_{2}\right)\end{array}$ & $\begin{array}{l}\text { Kewajiban bank atas dana-dana pihak ketiga yang telah dihimpun oleh bank } \\
\text { syariah, beban ini dicatat dalam laporan laba rugi. }\end{array}$ & Jutaan Rupiah \\
\hline Independen & $\begin{array}{l}\text { Total Pembiayaan } \\
\left(Q_{1}\right)\end{array}$ & $\begin{array}{l}\text { Aktiva produktif bank yang menghasilkan. Pembiayaan pada bank syariah } \\
\text { antara lain dalam bentuk pembiayaan Mudharabah dan Musyarakah. }\end{array}$ & Jutaan Rupiah \\
\hline Independen & $\begin{array}{l}\text { Surat Berharga } \\
\text { yang Dimiliki }\left(Q_{2}\right)\end{array}$ & $\begin{array}{l}\text { Aset bank dalam bentuk sekuritas yang pencatatannya pada neraca pada } \\
\text { sisi aktiva. }\end{array}$ & Jutaan Rupiah \\
\hline
\end{tabular}

\subsection{Metode Analisis Data}

Dalam penelitian ini digunakan perhitungan efisiensi Bank Umum Syariah dari sisi biaya dengan menggunakan metode pendekatan cost efficiency, sedangkan untuk perhitungannya menggunakan metode pendekatan parametrik Stochastic Frontier Approach (SFA) dan non parametrik Data Envelopment Analysis (DEA) yang menghitung deviasi dari fungsi biaya yang diestimasikan terlebih dahulu dengan profit frontier-nya. Efisiensi biaya diartikan sebagai rasio antara biaya minimum dimana perusahaan dapat menghasilkan sejumlah output tertentu, dengan biaya sebenarnya yang dikeluarkan oleh perusahaan perbankan tersebut. Semakin kecil biaya sebenarnya yang digunakan dibandingkan dengan biaya minimum, maka tingkat efisiensi biaya bank akan semakin besar. 


\section{Stochastic Frontier Approach}

Perangkat lunak Frontier 4.1 digunakan untuk mengestimasi fungsi biaya dengan menggunakan metode panel data pada pendekatan parametrik Stochastic Frontier Approach (SFA). Fungsi standar stochastic cost frontier memiliki bentuk umum (log) sebagai berikut:

$$
\ln C_{i}=f\left(\ln X_{j i}, \ln Y_{k i}\right)+e_{i}
$$

dimana $C_{i}$ adalah total biaya bank $n ; X_{j i}$ adalah input j pada bank $n ; Y_{j i}$ adalah output $k$ pada bank $n$; dan $e_{i}$ adalah galat. $e_{i}$ terdiri dari 2 fungsi yaitu:

$$
e_{i}=u_{i}+v_{i}
$$

dimana $u_{i}$ adalah faktor error yang dapat dikendalikan; dan $v_{i}$ adalah faktor error yang bersifat random yang tidak dapat dikendalikan. Diasumsikan bahwa $v$ terdistribusi normal $\mathrm{N}\left(0, \sigma_{\mathrm{v}}^{2}\right)$ dan u terdistribusi half-normal, $\left|\mathrm{N}\left(0, \sigma_{\mathrm{v}}^{2}\right)\right|$ di mana $\mathrm{u}_{\mathrm{it}}=\left(\mathrm{u}_{\mathrm{i}} \exp (-\mathrm{h}(\mathrm{t}-\mathrm{T}))^{3}\right.$ dan $h$ adalah parameter yang akan diestimasi.

Cost efficiency di-derivasi dari suatu fungsi biaya, misalkan fungsi biaya dengan bentuk persamaan umum (log) sebagai berikut:

$$
\ln C=f(w, y)+e
$$

Dengan menggunakan bentuk persamaan stochastic cost frontier maka persamaan biaya dapat dituliskan sebagai berikut:

$$
\ln C=f(w, y)+\ln u+\ln v
$$

dimana $\mathrm{C}$ adalah total biaya atau cost efficiency; w adalah jumlah input; $y$ adalah jumlah output; dan $u$ dan $v$ adalah galat.

Maka, cost efficiency dapat dituliskan sebagai berikut:

$$
C E F F n=\frac{c_{\min }}{c_{n}}=\frac{\exp \left[f c\left(w^{n}, y^{n}\right)+\ln \left(U c_{\min }\right)\right]}{\exp \left[f c\left(w^{n}, y^{n}\right)+\ln \left(U c_{n}\right)\right]}=\frac{U c_{\min }}{U c_{n}}
$$

\section{Data Envelopment Analysis}

Perangkat lunak WDEA digunakan untuk mengestimasi fungsi biaya dengan menggunakan metode panel data pada pendekatan non parametrik Data Envelopment Analysis (DEA). Data Envelopment Analysis merupakan metode non parametrik yang digunakan dalam mengukur tingkat efisiensi suatu Unit Kegiatan Ekonomi (UKE). 
Pada penelitian ini, akan digunakan model dengan asumsi constant return to scale (CRS) atau disebut dengan model CCR (Charnes-Cooper-Rhodes). Model tersebut dipilih berdasarkan penelitian yang dilakukan oleh Suseno (2008) tentang belum adanya hubungan antara tingkat efisiensi Bank Syariah (studi pada 10 Bank Syariah) dengan skala produksinya. Dalam penelitian tersebut dijelaskan bahwa skala ekonomi dalam industri perbankan tidak terjadi menurut skala perusahaan disebabkan fungsi suatu bank telah terintegrasi dengan bank lainnya.

\section{Analisis Regresi Berganda}

Berbeda dengan alat analisis lainnya, regreasi linear ganda memerlukan uji persyaratan yang sangat ketat. Setelah persamaan regresi linear berganda terbentuk, perlu dilakukan beberapa uji asumsi klasik, yaitu uji autokorelasi, uji heteroskedastisitas, dan uji multikolinearitas.

Selanjutnya dilakukan uji statistik. Secara statistik untuk mengetahui seberapa besar variabel-variabel bebas (variabel independen) secara serentak dapat menerangkan variabel tidak bebas (variabel dependen) dapat dilihat dari besarnya koefisien korelasi ganda atau $\mathrm{R}^{2}$. Dikarenakan terdapat lebih dari 2 variabel independen, maka digunakan uji Adjusted $\mathrm{R}$ Square.

Selanjutnya, untuk mengetahui signifikansi pengaruh semua variabel independen secara bersama-sama terhadap variabel dependen digunakan Uji F, yaitu dengan membandingkan $\mathrm{F}_{\text {hitung }}$ yang dihasilkan oleh regresi linear berganda dengan $\mathrm{F}_{\text {tabel }}$ pada taraf signifikan sebesar 95\% $(\alpha=5 \%)$. Jika $F_{\text {hitung }}>F_{\text {tabel }}$ maka variabel independen secara bersama-sama signifikan berpengaruh terhadap variabel dependen.

Serta, uji t digunakan untuk menguji kuatnya hubungan masing-masing variabel independen terhadap variabel dependen secara individu. Dengan membandingkan antara nilai $t_{\text {hitung }}$ dengan $t_{\text {tabel }}$ yang didapat dari masing-masing variabel dengan menggunakan taraf signifikan 95\% $(\alpha=5 \%)$. Jika $t_{\text {hitung }}>t_{\text {tabel }}$ pada tiap variabel independen maka variabel independen tersebut signifikan berpengaruh terhadap variabel dependen.

\section{HASIL DAN ANALISIS}

\subsection{Analisis Tingkat Efisiensi Biaya Bank Umum Syariah}

Dengan menggunakan metode Stochastic Frontier Approach (SFA) dan Data Envelopment Analysis (DEA), tingkat efisiensi dari masing-masing Bank Umum Syariah dapat diukur. Tingkat efisiensi tersebut dianalisis dari model fungsi biaya dengan variabel dependen total biaya/total cost (TC), input yang terdiri dari beban personalia (P1) dan beban bagi hasil (P2), sedangkan variabel output yaitu total pembiayaan (Q1) dan surat berharga yang dimiliki (Q2). 
Fungsi biaya yang dihasilkan adalah dalam bentuk model frontier yang merupakan model translog bukan sebuah model linear atau garis lurus, oleh karena itu semua variabel dalam penelitian ini yaitu TC, P1, P2, Q1, dan Q2 diubah dalam bentuk In (Kumbhakar, 2003 - dalam Edy Hartono).

\section{Tingkat Efisiensi Metode Stochastic Frontier Approach (SFA)}

Pengolahan data dilakukan dengan menggunakan perangkat lunak Frontier 4.1. Bentuk model prediksi tingkat efisiensi biaya pada BUS dapat ditulis sebagai berikut:

$$
\ln \mathrm{TC}=-0,267+0,542 \ln \mathrm{P} 1+0,538 \ln \mathrm{P} 2-0,971 \ln \mathrm{Q} 1+0,109 \ln \mathrm{Q} 2
$$

Dalam persamaan regresi di atas, konstanta TC adalah sebesar $-0,267$. Hal ini berarti apabila variabel input dan variabel output dianggap konstan, maka BUS akan mengeluarkan biaya minimum untuk tingkat output tertentu yaitu sebesar 0,7657 juta dari total aktiva ( $e^{x}$ $-0,267=0,7657)$.

Pada variabel input yaitu beban personalia (InP1) koefisien regresi 0,542 menunjukan bahwa jika eksponen beban personalia mengalami peningkatan sebesar 1\%, maka total biaya akan meningkat sebesar 0,542\%. Hal tersebut menunjukkan bahwa beban yang dikeluarkan BUS untuk karyawan tidak memberikan kontribusi yang positif bagi BUS, sehingga makin besar beban personalia, maka beban biaya total yang ditanggung BUS akan meningkat dan akan menyebabkan inefisiensi.

Dan beban bagi hasil (InP2) koefisien regresi 0,538 menunjukan bahwa jika eksponen beban bagi hasil mengalami peningkatan sebesar 1\%, maka total biaya akan mengalami peningkatan sebesar 0,538\%. Hal tersebut menunjukkan bahwa BUS belum optimal dalam mengelola Dana Pihak Ketiga (DPK) yang ada. DPK yang seharusnya dapat meningkatkan pendapatan bagi BUS, hanya menjadi beban karena BUS harus membayar return bagi nasabah penabungnya dan akan menimbulkan inefisiensi bagi BUS.

Sedangkan pada variabel output yaitu total pembiayaan (InQ1) koefisien regresi -0,971 menunjukan bahwa jika eksponen total pembiayaan mengalami peningkatan sebesar $1 \%$, maka total biaya akan mengalami penurunan sebesar 0,971\%. Hal tersebut menunjukkan bahwa pembiayaan yang diberikan oleh BUS berjalan dengan baik dan menghasilkan return yang baik pula. Namun, BUS harus terus meningkatkan produktivitas dari pembiayaan yang diberikan agar tingkat efisiensi BUS dapat terus meningkat.

Dan surat berharga yang dimiliki (InQ2) koefisien regresi 0,109 menunjukan bahwa jika eksponen surat berharga yang dimiliki mengalami peningkatan sebesar 1\%, maka total biaya akan mengalami peningkatan sebesar 0,109\%. Hal tersebut menunjukkan bahwa surat berharga yang dimiliki oleh BUS menghasilkan return yang lebih rendah daripada biaya yang harus dikeluarkan BUS pada surat berharga tersebut. 
Berikut hasil efisiensi biaya dengan metode SFA pada lima BUS.

\begin{tabular}{|c|c|c|c|c|c|}
\hline \multicolumn{6}{|c|}{$\begin{array}{c}\text { Tabel } 2 . \\
\text { Tingkat Efisiensi Biaya Bank Umum Syariah Metode SFA }\end{array}$} \\
\hline \multirow{2}{*}{ Periode } & \multicolumn{5}{|c|}{ Tingkat Efisiensi Biaya } \\
\hline & BMI & BSM & BMS & BRIS & BSB \\
\hline Maret 2010 & 0.9727 & 0.9459 & 0.9277 & 0.7545 & 0.9051 \\
\hline Juni 2010 & 0.9697 & 0.9032 & 0.9329 & 0.8827 & 0.8737 \\
\hline September 2010 & 0.9567 & 0.8825 & 0.8951 & 0.8162 & 0.8716 \\
\hline Desember 2010 & 0.9467 & 0.8417 & 0.8754 & 0.8096 & 0.8913 \\
\hline Maret 2011 & 0.8491 & 0.9708 & 0.9701 & 0.8399 & 0.9531 \\
\hline Juni 2011 & 0.8356 & 0.8247 & 0.9378 & 0.7630 & 0.9769 \\
\hline September 2011 & 0.8452 & 0.8081 & 0.9452 & 0.6433 & 0.9548 \\
\hline Desember 2011 & 0.7940 & 0.8093 & 0.9177 & 0.6960 & 0.9560 \\
\hline Maret 2012 & 0.7774 & 0.8445 & 0.9838 & 0.9549 & 0.9866 \\
\hline Juni 2012 & 0.7841 & 0.8482 & 0.9441 & 0.7948 & 0.9441 \\
\hline September 2012 & 0.7831 & 0.8645 & 0.9022 & 0.7944 & 0.9683 \\
\hline Desember 2012 & 0.7559 & 0.8705 & 0.8828 & 0.8644 & 0.9557 \\
\hline Maret 2013 & 0.7845 & 0.8980 & 0.9715 & 0.7100 & 0.6231 \\
\hline Juni 2013 & 0.7674 & 0.9322 & 0.9340 & 0.7339 & 0.5492 \\
\hline September 2013 & 0.7444 & 0.9281 & 0.9122 & 0.7795 & 0.5935 \\
\hline Desember 2013 & 0.7585 & 0.9009 & 0.8484 & 0.6984 & 0.5837 \\
\hline Rata-rata & 0,8328 & 0,8796 & 0,9238 & 0,7835 & 0,8492 \\
\hline
\end{tabular}

Tingkat efisiensi biaya dengan pendekatan SFA secara rata-rata keseluruhan BUS diketahui sebesar 0,8538 atau 85,38\%. Artinya BUS secara keseluruhan hanya efisien menggunakan biayanya sebesar $85,38 \%$, sedangkan sisanya $14,62 \%$ biaya terbuang. Diketahui juga bahwa BMS memiliki tingkat efisiensi biaya SFA tertinggi dibandingkan dengan BUS lainnya dan BUS secara keseluruhan, yaitu sebesar 0,9238 atau 92,38\%. BMS diketahui tidak terlalu besar target perolehan DPK. Hal inilah yang membuat BMS tidak terlalu terbebani dengan biaya dana DPK tersebut.Sedangkan BRIS memiliki tingkat efisiensi biaya SFA terendah, yaitu sebesar 0,7835 atau $78,35 \%$.

Rata-rata tingkat efisiensi biaya SFA pada BMI, BRIS, dan BSB masih berada di bawah rata-rata tingkat efisiensi seluruh BUS. Maka, agar dapat lebih berkompetisi, maka ketiga BUS tersebut harus lebih memangkas biaya-biaya yang tidak efektif.Dari hasil tingkat efisiensi biaya SFA juga memperlihatkan bahwa BUS secara keseluruhan belum mencapai tingkat efisiensi yang optimal. Oleh karena itu, peningkatan efisiensi biaya masih harus terus dilakukan. Tingkat efisiensi biaya SFA juga terlihat sangat variasi mulai dari 0,5492 (BSB periode Juni 2013) sampai dengan 0,9866 (BSB periode Maret 2012). Hal tersebut membuktikan bahwa setiap BUS memiliki strategi implementasi manajerial yang berbeda-beda dalam hal penekanan biaya bagi hasil, penekanan biaya personalia, pengaturan investasi, dan sebagainya. 


\section{Tingkat Efisiensi Metode Data Envelopment Analysis (DEA)}

Berikut adalah hasil tingkat efisiensi 5 BUS selama periode Januari 2010-Desember 2013 melalui metode Data Envelopment Analysis (DEA). Pengolahan data dilakukan dengan menggunakan perangkat lunak WDEA. Berikut hasil efisiensi biaya dengan metode DEA pada lima BUS.

\begin{tabular}{|c|c|c|c|c|c|}
\hline \multicolumn{6}{|c|}{$\begin{array}{c}\text { Tabel } 3 . \\
\text { Tingkat Efisiensi Biaya Bank Umum Syariah Metode DEA }\end{array}$} \\
\hline \multirow{2}{*}{ Periode } & \multicolumn{5}{|c|}{ Tingkat Efisiensi Biaya } \\
\hline & BMI & BSM & BMS & BRIS & BSB \\
\hline Maret 2010 & 0.1000 & 0.1000 & 0.1000 & 0.1000 & 0.9860 \\
\hline Juni 2010 & 0.9539 & 0.9496 & 0.9414 & 0.9481 & 0.9230 \\
\hline September 2010 & 0.9303 & 0.9208 & 0.9062 & 0.9096 & 0.8980 \\
\hline Desember 2010 & 0.9129 & 0.9011 & 0.8840 & 0.8866 & 0.8874 \\
\hline Maret 2011 & 0.1000 & 0.9858 & 0.9984 & 0.9682 & 0.9850 \\
\hline Juni 2011 & 0.9481 & 0.9335 & 0.9417 & 0.9105 & 0.9231 \\
\hline September 2011 & 0.9217 & 0.9035 & 0.9138 & 0.8770 & 0.8885 \\
\hline Desember 2011 & 0.9033 & 0.8821 & 0.8922 & 0.8581 & 0.8890 \\
\hline Maret 2012 & 0.1000 & 0.9697 & 0.1000 & 0.9731 & 0.9903 \\
\hline Juni 2012 & 0.9548 & 0.9225 & 0.9417 & 0.9127 & 0.9500 \\
\hline September 2012 & 0.9281 & 0.8974 & 0.9064 & 0.8883 & 0.9181 \\
\hline Desember 2012 & 0.9241 & 0.8798 & 0.8820 & 0.8821 & 0.8933 \\
\hline Maret 2013 & 0.1000 & 0.9748 & 0.9894 & 0.9768 & 0.1000 \\
\hline Juni 2013 & 0.9578 & 0.9267 & 0.9182 & 0.9321 & 0.1000 \\
\hline September 2013 & 0.9339 & 0.8986 & 0.8828 & 0.9030 & 0.9620 \\
\hline Desember 2013 & 0.9110 & 0.8782 & 0.8597 & 0.8859 & 0.9348 \\
\hline Rata-rata & 0.9487 & 0.9265 & 0.9286 & 0.9195 & 0.9393 \\
\hline
\end{tabular}

Tingkat efisiensi biaya dengan pendekatan DEA secara rata-rata keseluruhan BUS diketahui sebesar 0,9325 atau 93,25\%. Artinya BUS secara keseluruhan dapat mencapai tingkat output yang maksimal dengan hanya mengeluarkan kurang dari 93,25\% dari input yang dimilikinya. Diketahui juga bahwa BMI memiliki tingkat efisiensi biaya DEA tertinggi dibandingkan dengan BUS lainnya dan BUS secara keseluruhan, yaitu sebesar 0,9487 atau 94,87\%. Sedangkan BRIS memiliki tingkat efisiensi biaya DEA terendah, yaitu sebesar 0,9195 atau 91,95\%.

BSM, BMS, dan BRIS memiliki tingkat efisiensi biaya yang lebih rendah dari rata-rata tingkat efisiensi pada seluruh BUS dengan metode DEA. Dari hasil tingkat efisiensi biaya DEA juga memperlihatkan bahwa BUS secara keseluruhan belum mencapai tingkat efisiensi yang optimal. Oleh karena itu, peningkatan efisiensi biaya masih harus terus dilakukan. Ada berbagai cara untuk dapat mengoptimalkan tingkat efisiensi pada BUS. Salah satunya dengan melihat table of target values dari output WDEA dan tanpa menghitung, maka target variabel input output harus diubah dan disesuaikan. Dengan demikian masing-masing BUS dapat memperoleh tingkat efisiensi optimal. 
Tingkat efisiensi biaya DEA juga terlihat sangat variasi mulai dari 0,100 sampai dengan 0,8581 . Hal tersebut membuktikan bahwa setiap BUS memiliki strategi implementasi manajerial yang berbeda-beda dalam hal penekanan biaya bagi hasil, penekanan biaya personalia, pengaturan investasi, dan sebagainya.

\subsection{Perbedaan Tingkat Efisiensi Biaya dengan Menggunakan Metode SFA dan DEA}

Berdasarkan hasil analisis metode SFA dan DEA di atas, maka dapat diketahui tingkat efisiensi biaya pada masing-masing BUS selama periode 2010-2013, yaitu.

\begin{tabular}{|c|c|c|} 
Tabel 4. \\
Perbandingan Tingkat Efisiensi Biaya BUS \\
Metode SFA dan DEA \\
\hline BUS & $\begin{array}{c}\text { Tingkat Efisiensi } \\
\text { Biaya SFA }\end{array}$ & $\begin{array}{c}\text { Tingkat Efisiensi } \\
\text { Biaya DEA }\end{array}$ \\
\hline BMI & $83,28 \%$ & $94,87 \%$ \\
BSM & $87,96 \%$ & $92,65 \%$ \\
BMS & $92,38 \%$ & $92,86 \%$ \\
BRIS & $78,35 \%$ & $91,95 \%$ \\
BSB & $84,92 \%$ & $93,93 \%$ \\
\hline
\end{tabular}

Dari tabel di atas diketahui bahwa tingkat efisiensi biaya pada kelima BUS baik dengan metode SFA maupun DEA, belum optimal karena tidak ada yang mencapai 100\%. Namun, terdapat ketidaksamaan hasil efisiensi biaya dengan metode SFA dan DEA. Pada metode SFA, BMS memiliki tingkat efisiensi biaya tertinggi, sedangkan pada metode DEA BMI yang memiliki tingkat efisiensi tertinggi. Dan BRIS merupakan BUS yang memiliki tingkat efisiensi biaya terendah dari kelima BUS, baik dengan metode SFA maupun DEA.

Dibandingkan dengan DEA, metode SFA memerlukan informasi yang akurat untuk harga input dan variabel eksogen lainnya. SFA juga mempertimbangkan beberapa deviasi sebagai pengganggu (noise) dalam model regresi. Kemudian, mempertimbangkan beberapa deviasi yang merupakan gambaran dari inefisiensi, pada pendekatan DEA disebut sebagai deterministic frontier. Sedangkan pada metode DEA tidak menggunakan informasi, sehingga sedikit data yang dibutuhkan, lebih sedikit asumsi yang diperlukan dan sampel yang lebih sedikit dapat dipergunakan. Namun, kesimpulan secara statistika tidak dapat diambil jika menggunakan metode DEA.

Meskipun SFA lebih memiliki kelengkapan dalam mengestimasi tingkat efisiensi, bukan berarti DEA tidak mempunyai keunggulan. Dalam mengukur efisiensi, DEA mengidentifikasi unit yang digunakan sebagai referensi yang dapat membantu untuk mencari penyebab dan jalan 
keluar dari ketidakefisienan (Hadad et al: 2003). Selain itu, DEA tidak memerlukan spesifikasi yang lengkap dari bentuk fungsi yang menunjukkan hubungan produksi dan distribusi dari observasi.

Pada pemaparan selanjutnya dapat dilihat bahwa distribusi data dalam uji asumsi klasik pada penelitian ini memenuhi asumsi normalitas dan memenuhi asumsi homogenitas. Hal ini nantinya akan berpengaruh terhadap estimasi regresi dari pendekatan SFA sehingga model yang diajukan dapat representatif. Terpenuhinya asumsi normalitas dan homogenitas dapat disebabkan oleh pengukuran yang dilakukan pada masing-masing BUS dan tidak dilakukan pada keseluruhan BUS. Sehingga data dapat lebih seimbang.

Maka dalam penelitian ini SFA lebih sesuai untuk mengukur tingkat efisieni biaya pada kelima BUS. Metode SFA dapat memperkirakan adanya sampel error yang tak terhingga, khususnya jika variabel input dan output relatif lebih banyak dibandingkan dengan banyaknya variabel observasi (Hadad et al. 2003).

Hasil efisiensi biaya dengan metode SFA, dapat dibagi berdasarkan beberapa kategori. Adapun nilai rata-rata efisiensi biaya dengan metode SFA yaitu sebesar 0,853765 dengan standar deviasi 0,101588. Pengelompokkan nilai efisiensi biaya SFA menjadi empat kategori dengan menggunakan persentil kuartile \pm standar deviasi adalah sebagai berikut.

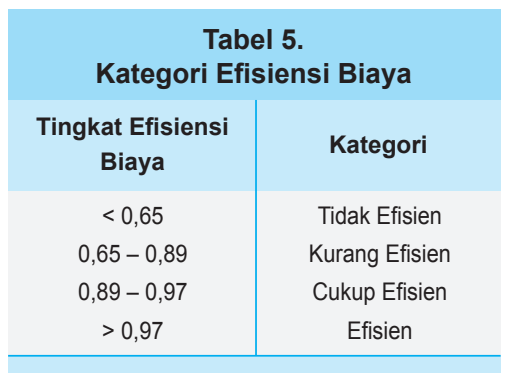

Maka, kelima BUS dapat dikelompokkan sebagai berikut.

\begin{tabular}{l|c|c|}
\hline \multicolumn{3}{|c}{ Tabel 6. } \\
\multicolumn{2}{|c|}{ Pengelompokkan Tingkat Efisiensi } \\
\hline \multicolumn{1}{|c|}{ BUS } & Tingkat Efisiensi & Kategori \\
\hline Bank Muamalat Indonesia & $83,28 \%$ & Kurang Efisien \\
Bank Syariah Mandiri & $87,96 \%$ & Kurang Efisien \\
Bank Mega Syariah & $92,38 \%$ & Cukup Efisien \\
BRI Syariah & $78,35 \%$ & Kurang Efisien \\
Bank Syariah Bukopin & $84,92 \%$ & Kurang Efisien \\
\hline
\end{tabular}

Berdasarkan tabel di atas, dapat disimpulkan bahwa BMI, BSM, BRIS, dan BSB termasuk dalam kategori bank yang kurang efisien dalam mengelola dananya. Sedangkan BMS termasuk 
bank yang cukup efisien dalam mengelola dananya. Hasil ini menunjukkan bahwa tidak ada BUS yang beroperasi secara efisien. Untuk itu, perlu adanya perbaikan-perbaikan dalam meningkatkan kinerja efisiensi BUS.

\subsection{Pengaruh Variabel Input-Output Terhadap Efisiensi Bank Umum Syariah}

Hasil uji normalitas data menunjukkan bahwa hanya BRIS yang tidak berdistribusi secara normal dan tidak memenuhi uji normalitas data. Dari hasil uji autokorelasi dapat disimpulkan bahwa tidak terdapat autokorelasi, kecuali pada Bank Muamalat. Dari diagram scatterplot yang merupakan hasil uji heteroskedastisitas, (tidak ditampilkan), dapat disimpulkan bahwa model regresi pada kelima BUS telah bebas dari gejala heteroskedastisitas. Berdasarkan uji multikolinearitas dari masing-masing bank, diketahui bahwa variabel independen pada seluruh BUS mengalami masalah multikolinearitas. ${ }^{2}$

Selanjutnya, dilakukan analisis pengaruh variabel input dan output terhadap efisiensi biaya pada masing-masing BUS. Hasil estimasi terhadap lima BUS mengenai pengaruh variabel input dan output terhadap efisiensi biaya menunjukkan koefisien determinasi yang baik sebagaimana ditunjukkan yang baik sebagaimana ditunjukkan dalam adjusted $R$ square berikut.

\begin{tabular}{|c|c|c|c|c|c|c|}
\hline \multicolumn{7}{|c|}{$\begin{array}{c}\text { Tabel } 7 . \\
\text { Hasil Uji Adjusted R Square (Adj R²) }\end{array}$} \\
\hline & BMI & BSM & BMS & BRIS & BSB & Keseluruhan BUS \\
\hline Adj $R^{2}$ & 0,987 & 0,988 & 0,998 & 0,926 & 0,964 & 0,983 \\
\hline
\end{tabular}

Nilai Adjusted R Square keseluruhan BUS dari model regresinya adalah sebesar 0,983 atau 98,3\% yang menunjukkan variabel bebas (beban personalia, beban bagi hasil, total pembiayaan, dan surat berharga yang dimiliki) secara bersama-sama dapat menerangkan variabel terikat (total biaya) sebesar 98,3\% dan sisanya 1,7\% dijelaskan variabel lain yang tidak dimasukan dalam model empiris.

Uji F untuk masing-masing sampel menunjukkan spesifikasi model yang cukup baik. Berikut tabel yang akan membandingkan hasil Uji t pada masing-masing BUS dengan hasil Uji t pada keseluruhan BUS.

2 Permasalahan ini diharapkan dapat diatasi pada penelitian mendatang. 


\begin{tabular}{|c|c|c|c|c|c|c|}
\hline \multicolumn{7}{|c|}{$\begin{array}{c}\text { Tabel } 8 . \\
\text { Hasil Uji t Keseluruhan }\end{array}$} \\
\hline Variabel & BMI & BSM & BMS & BRIS & BSB & Keseluruhan BUS \\
\hline Beban Personalia & $t^{*}$ & + & $t^{*}$ & - & $t^{*}$ & $t^{*}$ \\
\hline Beban Bagi Hasil & $t^{*}$ & $+^{*}$ & $t^{*}$ & $+^{*}$ & $-^{*}$ & $t^{*}$ \\
\hline Total Pembiayaan & $t^{*}$ & + & $-^{*}$ & $-^{*}$ & $t^{*}$ & $-*$ \\
\hline Surat Berharga & $-^{*}$ & -* & - & $-^{*}$ & - & + \\
\hline
\end{tabular}

\subsection{Perbandingan Tingkat Efisiensi Biaya dan Tingkat Profitabilitas Bank Umum Syariah}

Indikator yang umum digunakan untuk mengukur tingkat profitabilitas adalah ROA (Return on Assets). Rasio ROA adalah rasio yang menunjukan kemampuan dari keseluruhan aktiva yang ada dan yang digunakan untuk menghasilkan keuntungan.

Berikut rata-rata tingkat profitabilitas pada kelima BUS selama periode 2010 sampai 2013.

\begin{tabular}{|c|c|c|c|c|c|}
\hline \multicolumn{6}{|c|}{$\begin{array}{c}\text { Tabel } 9 . \\
\text { Rata-RataTingkat Profitabilitas Bank Umum Syariah }\end{array}$} \\
\hline & BMI & BSM & BMS & BRIS & BSB \\
\hline ROA & $1,48 \%$ & $2,09 \%$ & $2,77 \%$ & $0,83 \%$ & $0,59 \%$ \\
\hline
\end{tabular}

Hasil profitabilitas di atas, dapat dikelompokkan menjadi lima kategori berdasarkan Surat Edaran Bank Indonesia No. 13/24/DPNP tanggal 25 Oktober 2011.

\begin{tabular}{c|c}
\multicolumn{2}{|c}{ Tabel 10.} \\
Kategori Profitabilitas \\
$\begin{array}{c}\text { Tingkat } \\
\text { Profitabilitas }\end{array}$ \\
$<0 \%$ & Kategori \\
$0 \%-0,5 \%$ & Rugi \\
$0,5 \%-1,25 \%$ & Tidak Profitabilitas \\
$1,25 \%-1,5 \%$ & Profitabilitas Kurang \\
$>1,5 \%$ & Profitabilitas Cukup \\
& \\
\hline
\end{tabular}


Maka, kelima BUS dapat dikelompokkan sebagai berikut.

\begin{tabular}{l|c|c|}
\hline \multicolumn{2}{|c|}{$\begin{array}{c}\text { Tabel 11. } \\
\text { Pengelompokkan Profitabilitas }\end{array}$} \\
\multicolumn{1}{|c|}{ BUS } & $\begin{array}{c}\text { Tingkat } \\
\text { Profitabilitas }\end{array}$ & Kategori \\
\hline Bank Muamalat Indonesia & $1,48 \%$ & Profitabilitas Cukup \\
Bank Syariah Mandiri & $2,09 \%$ & Profitabilitas Tinggi \\
Bank Mega Syariah & $2,77 \%$ & Profitabilitas Tinggi \\
BRI Syariah & $0,83 \%$ & Profitabilitas Kurang \\
Bank Syariah Bukopin & $0,59 \%$ & Profitabilitas Kurang \\
\hline
\end{tabular}

Berikut tabel yang memperlihatkan hasil tingkat efisiensi biaya dan tingkat profitabilitas pada kelima BUS periode 2010-2013.

\begin{tabular}{l|c|c}
\hline \multicolumn{3}{|c}{ Tabel 12.} \\
\multicolumn{1}{|c|}{ Kinerja Bank Umum Syariah Periode 2010-2013 } \\
\hline Bank Muamalat Indonesia & $\begin{array}{c}\text { Kategori } \\
\text { Efisiensi Biaya }\end{array}$ & $\begin{array}{c}\text { Kategori } \\
\text { Profitabilitas }\end{array}$ \\
Bank Syariah Mandiri & $\begin{array}{c}\text { Kurang Efisien } \\
\text { Kurang Efisien }\end{array}$ & Profitabilitas Cukup \\
Bank Mega Syariah & $\begin{array}{l}\text { Cukup Efisien } \\
\text { Kurang Efisien }\end{array}$ & Profitabilitas Tinggi \\
BRI Syariah & Profitabilitas Kurang \\
Bank Syariah Bukopin & Kurang Efisien & Profitabilitas Kurang \\
\hline
\end{tabular}

Dari tabel di atas menunjukkan terdapat ketidakselarasan antara hasil tingkat efisiensi dan tingkat profitabilitas BUS. Diantaranya pada BMI, BSM, dan BMS.

Pada BMI diketahui memiliki tingkat efisiensi biaya kurang efisien dan memiliki profitabilitas yang cukup. Artinya, BMI belum mengelola dananya dengan efisien. BMI masih belum memangkas dana-dana yang tidak penting, sehingga profitabilitas BMI menjadi tidak optimum. Berdasarkan laporan keuangan BMI diketahui bahwa hingga Mei 2014 pertumbuhan laba BMI hanya mencapai 3\%. Hal tersebut terjadi karena biaya dana mengalami peningkatan. Selain itu, pada RUPS (Rapat Umum Pemegang Saham) Tahunan pada akhir Juni 2014 disetujui bahwa penggunaan laba bersih perseroan untuk tahun buku 2013 setelah pajak sebesar Rp 475,8 miliar dipergunakan untuk cadangan perseroan, tidak ada pembagian dividen bagi pemegang saham (Republika, Februari 2015). BMI juga sangat gencar untuk menjaring DPK. Mulai dari promosi berupa pemberian hadiah-hadiah maupun memberikan tingkat bagi hasil yang tinggi melebihi BI Rate. Hal inilah yang harus diperhitungkan oleh manajemen BMI, agar peningkatan dana DPK juga harus diikuti dengan peningkatan optimalisasi return dari pengelolaan DPK tersebut. 
Pada BSM diketahui memiliki tingkat efisiensi yang kurang dan memiliki profitabilitas yang tinggi. Artinya, BSM belum mengelola dana dengan efisien. Namun, profitabilitas yang tinggi dapat diperoleh BSM. Hal tersebut dikarenakan BSM menetapkan nisbah bagi hasil kepada nasabah peminjam termasuk tinggi. Agar BSM dapat lebih kompetitif, maka tingkat efisiensi biaya harus ditingkatkan, sehingga BSM dapat memberikan nisbah yang lebih rendah dan kompetitif dengan bank lainnya. Selain itu, BSM banyak mengeluarkan produk-produk yang laku di pasaran, seperti Gadai dan Cicil Emas, serta Tabungan Haji. Omset produk Gadai Emas BSM mencapai Rp 2,05 triliun dan tiap bulan omset meningkat sekitar 16,25\% (Metrotvnews. com, September 2014). Sedangkan untuk Tabungan Haji, BSM juga terus memperluas pangsa pasarnya, BSM ingin dikenal sebagai bank haji dan umroh. Untuk itu, BSM ikut serta dalam International Islamic Expo 2013, di mana mempromosikan produk-produk dan pelayanan terkait haji dan umroh (Infobank, Desember 2013). Dapat disimpulkan, BSM memiliki produk yang lebih unggul dari BUS lainnya, sehingga BSM dapat memperoleh laba yang tinggi. Namun, laba tersebut sebenarnya dapat lebih ditingkatkan yaitu dengan melakukan efisiensi pada biaya-biaya yang dapat diminimalisir pengeluarannya.

Pada BMS diketahui memiliki tingkat efisiensi yang cukup baik dan tingkat profitabilitas yang tinggi. Artinya, BMS sebagai BUS dengan aset yang tidak besar mampu mengelola dananya dengan optimal sehingga memiliki tingkat profitabilitas yang tinggi dan juga tidak terlalu terbebani dengan DPK sehingga tingkat efisiensi cukup baik. Laba BMS pada akhir tahun 2013 meningkat sebesar 13,09\% dibandingkan tahun sebelumnya. BMS diketahui tidak terlalu besar target perolehan DPK. Hal inilah yang membuat BMS tidak terlalu terbebani dengan biaya dana DPK tersebut. BMS fokus pada pembiayaan yang didominasi oleh joint financing kendaraan roda dua, di mana pembiayaan tersebut terus mengalami peningkatan sebesar $56,52 \%$ dari tahun sebelumnya (Bisnis Indonesia, Februari 2014).

Pada BRIS diketahui memiliki tingkat efisiensi dan profitabilitas yang kurang. Artinya, BRIS harus terus meningkatkan efisiensi biaya dengan mengurangi biaya-biaya yang tidak penting yang tidak dapat meningkatkan profitabilitas. Diharapkan dengan semakin efisien maka tingkat profitabilitas juga akan meningkat. BRIS mengalami penurunan laba drastis pada periode pertama tahun 2014, yaitu turun sebesar 97,73\%. Hal tersebut kemungkinan terjadi karena beberapa hal. Salah satunya, mayoritas portofolio pembiayaan pada BRIS adalah murabahah (jual-beli), di mana margin pembiayaan sudah disepakati di awal. Sehingga, ketika ada kenaikkan margin deposito, BRIS tidak dapat menaikkan margin pembiayaan murabahah tersebut. Maka, BRIS pun harus menanggung biaya dana yang meningkat tersebut tanpa diimbangi dengan peningkatan pendapatan (Kontan, Agustus 2014). Di sisi lain pertumbuhan DPK pada BRIS hanya tumbuh 3,19\%.

Pada BSB diketahui bahwa memiliki tingkat efisiensi yang kurang dan juga memiliki tingkat profitabilitas yang kurang. Artinya, pengelolaan dana pada BSB belum baik. BSB belum mampu meminimalisir biaya-biaya yang tidak penting. BSB juga sangat selektif dalam menyalurkan 
pembiayaan. Pembiayaan murabahah di mana return yang didapat bank fix (tetap), dianggap menekan laba bagi BSB. Oleh karena itu, BSB harus mampu menempatkan dananya pada investasi-investasi yang memberikan keuntungan yang baik, sehingga profitabilitas BSB dapat meningkat dan dari profitabilitas tersebut dapat mengurangi beban biaya pada BSB.

\subsection{Implikasi Manajerial}

Tingkat persaingan harga yang makin ketat pada perbankan menuntut Bank Umum Syariah untuk mampu memberikan harga yang kompetitif bagi para nasabah. Dengan meminimalisir biaya-biaya, BUS akan mampu memberikan harga yang lebih kompetitif. Oleh karena itu, perhitungan efisiensi biaya sangatlah diperlukan. Efisiensi biaya diartikan sebagai rasio antara biaya minimum dimana perusahaan dapat menghasilkan sejumlah output tertentu, dengan biaya sebenarnya yang dikeluarkan oleh perusahaan perbankan tersebut. Semakin kecil biaya sebenarnya yang digunakan dibandingkan dengan biaya minimum, maka tingkat efisiensi biaya bank akan semakin besar. Bagian di bawah ini mengulas rekomendasi implikasi manajerial berdasarkan hasil penelitian.

\subsection{Bank Muamalat Indonesia}

BMI memiliki tingkat efisiensi biaya yang rendah dan tingkat profitabilitas yang cukup baik. Dari hasil tersebut diketahui bahwa BMI masih banyak terbebani oleh biaya-biaya yang seharusnya dapat diminimalisir. Beban bagi hasil dan beban personalia secara signifikan meningkatkan total biaya pada BMI. Untuk itu, BMI perlu lebih mengoptimalkan DPK untuk disalurkan dalam bentuk pembiayaan agar DPK tersebut mampu memberikan return bagi BMI dan tidak hanya menjadi beban bagi BMI. Beban personalia juga harus dipangkas karena hanya menjadi beban bagi BMI selama ini tanpa diikuti dengan peningkatan kinerja karyawan. Namun, total pembiayaan pada BMI juga berpengaruh signifikan meningkatkan total biaya pada BMI. Hal ini mungkin terjadi karena margin pembiayaan yang tinggi sehingga pembiayaan yang disalurkan tidak optimal dalam memberikan keuntungan bagi BMI. Selain itu, agar dapat bersaing BMI memberikan margin yang lebih rendah tetapi margin tersebut belum dapat menutupi biaya BMI.

\section{Bank Syariah Mandiri}

BSM memiliki tingkat efisiensi yang cukup baik dan tingkat profitabilitas yang tinggi. Dari hasil tersebut diketahui BSM dengan aset yang besar mampu menghasilkan profit yang tinggi dan efisiensi biaya yang cukup baik walaupun belum optimal. Dalam meningkatkan efisiensi biaya, BSM perlu meningkatkan penempatan dananya pada investasi-investasi yang menguntungkan seperti surat berharga. Dari hasil analisis diketahui bahwa surat berharga signifikan mengurangi 
total biaya pada BSM. Selain itu, beban bagi hasil juga signifikan meningkatkan total biaya pada BSM. Oleh karena itu, BSM perlu mengelola DPK dengan baik agar DPK tersebut dapat memberikan keuntungan bagi BSM dan tidak hanya menjadi beban bagi BSM.

\section{Bank Mega Syariah}

BMS memiliki tingkat efisiensi biaya yang cukup baik dan tingkat profitabilitas yang tinggi. dari hasil tersebut diketahui BMS belum optimal melakukan efisiensi biaya. Beban bagi hasil dan beban personalia secara signifikan meningkatkan total biaya pada BMS. Oleh karena itu, BMS perlu lebih mengoptimalkan DPK untuk disalurkan dalam bentuk pembiayaan agar DPK tersebut mampu memberikan return bagi BMS dan tidak hanya menjadi beban bagi BMS. Beban personalia juga harus dipangkas karena hanya menjadi beban bagi BMS selama ini tanpa diikuti dengan peningkatan kinerja karyawan. Strategi lainnya, total pembiayaan pada BMS harus lebih ditingkatkan karena total pembiayaan signifikan menurunkan total biaya pada BMS.

\section{BRI Syariah}

BRIS memiliki tingkat efisiensi biaya dan profitabilitas yang rendah. Untuk itu, perlu pengelolaan yang lebih baik bagi BRIS. Dari hasil analisis diketahui beban bagi hasil signifikan meningkatkan total biaya pada BRIS. Oleh karena itu, BRIS perlu mengelola DPK dengan baik agar DPK tersebut dapat memberikan keuntungan bagi BRIS dan tidak hanya menjadi beban bagi BRIS. Total pembiayaan dan surat berharga yang dimiliki BRIS juga secara signifikan menurunkan total biaya pada BRIS. Maka, BRIS harus lebih meningkatkan pembiayaan dan investasi yang menguntungkan dan aman.

\section{Bank Syariah Bukopin}

BSB memiliki tingkat efisiensi biaya dan profitabilitas yang rendah. Dari hasil analisis diketahui bahwa beban bagi hasil dan surat berharga yang dimiliki BSB signifikan meningkatkan total biaya BSB. Oleh karena itu, BSB perlu mengelola DPK dengan baik agar DPK tersebut dapat memberikan keuntungan bagi BSB dan tidak hanya menjadi beban bagi BSB. Selain itu, penempatan aset pada investasi seperti surat berharga juga harus lebih diperhatikan agar investasi tersebut mampu menghasilkan profit bagi BSB. Pada beban personalia diketahui signifikan menurunkan total biaya pada BSB. Hal tersebut berarti beban personalia yang ada mampu meningkatkan kinerja karyawan BSB, sehingga output yang dihasilkan semakin optimal. Namun, pada jangka panjang, peningkatan beban personalia tidak selalu meningkatkan tingkat efisiensi. Untuk itu, BSB perlu terus berhati-hati dalam mengambil kebijakan. 


\section{Bank Umum Syariah Secara Keseluruhan}

Secara keseluruhan, tingkat efisiensi biaya pada BUS masih kurang efisien. Laba yang dihasilkan juga belum optimal. Beberapa faktor penyebab diantaranya adalah kurangnya modal atau aset pada BUS. BUS perlu meningkatkan aset agar dapat terus melakukan ekspansi pasar. Perolehan DPK pada BUS juga harus dioptimalkan. BUS harus kompetitif dalam memberikan return bagi nasabah DPK. Namun, BUS juga harus rasional dalam memberikan return, agar BUS tidak mengalami kerugian. Hal-hal lain yang harus dilakukan BUS yaitu mendesak bank umum konvensional selaku induk dari BUS untuk serius mendorong pengembangan bisnis anak usahanya. Serta BUS harus melakukan inovasi-inovasi produk yang menarik bagi nasabah dan sesuai dengan kebutuhan nasabah. Agar nasabah-nasabah yang rasional tidak berpaling ke bank konvensional. Selain itu, BUS juga harus memangkas biaya-biaya yang tidak penting. Misalnya, gaji direksi bank yang besar perlu dilakukan pemangkasan dan dialokasikan pada hal-hal lain yang lebih bermanfaat bagi bank.

\subsection{Implikasi Kebijakan Bagi Bank Indonesia}

Dari hasil analisis yang telah dilakukan, maka dapat disimpulkan bahwa dalam menghadapi MEA, perbankan syariah Indonesia khususnya BUS belum siap dalam persaingan dengan bankbank lain dari negara-negara ASEAN. Harga yang tidak kompetitif akan semakin sulit bagi BUS di Indonesia untuk mendapatkan DPK dan menyalurkan pembiayaan-pembiayaan.

Indonesia merupakan pasar terbesar di dunia bagi perbankan syariah. Hal tersebut harusnya menjadi pendorong bagi BUS agar lebih efisien dalam mengelola dananya dan berani untuk menawarkan harga yang lebih kompetitif agar pangsa pasar nasional yang besar tersebut dapat dinikmati. Tentunya masyarakat Indonesia akan lebih banyak memilih dengan rasionalitas, bukan secara emosional. Sehingga jika BUS tidak dapat memberikan harga yang menarik, maka masyarakat akan dengan mudah berpaling ke bank lainnya, baik bank syariah lain atau bank konvensional yang lebih menguntungkan.

Berikut beberapa rekomendasi implikasi kebijakan bagi Bank Indonesia berdasarkan hasil penelitian:

1. Salah satu misi dari BI adalah mendorong sistem keuangan nasional agar bekerja secara efisien. Oleh karena itu, perlu bagi BI menjadikan perhitungan tingkat efisiensi dengan menggunakan pendekatan frontier (SFA dan DEA) sebagai alternatif atau pendukung dalam menilai kinerja perbankan, yang selama ini menggunakan rasio BOPO. Dengan pendekatan frontier, faktor-faktor penyebab inefisiensi dapat diketahui, sehingga peningkatan kinerja efisiensi perbankan dapat lebih mudah dicapai.

2. Perlu dibuat kriteria nilai tingkat efisiensi yang baku. Hal ini agar terjadi pemahaman yang sama terhadap nilai tingkat efisiensi dari suatu bank. 
3. BI harus memberikan perlakuan yang berbeda antara bank syariah dan bank konvensional. Dalam hal penyaluran dana, bank syariah tidak hanya dihadapkan pada persoalan mengenai keuntungan tetapi juga penyaluran dana harus berjalan sesuai dengan syariah. Oleh karena itu, BI perlu mengembangkan instrumen-instrumen keuangan syariah agar bank syariah dapat lebih meningkatkan investasinya.

4. Perlu dilakukan suatu kegiatan berkala pemberian penghargaan-penghargaan pada perbankan yang mengelola dananya dengan efisien. Diharapkan kegiatan tersebut dapat terus mendorong perbankan nasional agar lebih efisien, sehingga mampu bersaing dengan perbankan-perbankan asing yang ada di Indonesia.

\section{KESIMPULAN}

Hasil analisis mengenai tingkat efisiensi biaya pada Bank Umum Syariah (Bank Muamalat Indonesia, Bank Syariah Mandiri, Bank Mega Syariah, BRI Syariah, dan Bank Syariah Mega) selang periode 2010-2013, memberikan beberapa kesimpulan berikut:

1. Pada analisis tingkat efisiensi BUS periode 2010-2013, diketahui nilai rata-rata tingkat efisiensi biaya dengan model SFA dan DEA pada masing-masing BUS yaitu pada BMI sebesar 83,28\% dan 94,87; pada BSM sebesar 87,96\% dan 92,65\%; pada BMS sebesar 92,38\% dan 92,86\%; pada BRIS sebesar 78,35\% dan 91,95\%; pada BSB sebesar 84,92\% dan 93,93\%; dan pada keseluruhan BUS sebesar 85,38\% dan 93,25\%.

2. Dari hasil tersebut diketahui terdapat perbedaan hasil tingkat efisiensi biaya dengan metode SFA dan DEA. Pada penelitian ini SFA lebih sesuai untuk digunakan.

3. Hasil regresi menunjukkan bahwa variabel Beban Personalia, Beban Bagi Hasil, Total Pembiayaan, dan Surat Berharga yang Dimiliki berpengaruh signifikan terhadap tingkat efisiensi pada BMI. Pada BSM hanya Beban Bagi Hasil dan Surat Berharga yang Dimiliki yang berpengaruh signifikan terhadap tingkat efisiensi. Sedangkan pada BMS, Beban Personalia, Beban Bagi Hasil, dan Total Pembiayaan berpengaruh signifikan terhadap efisiensi. Adapun pada BRIS, Beban Bagi Hasil, Total Pembiayaan, dan Surat Berharga yang Dimiliki berpengaruh signifikan terhadap tingkat efisiensi. Pada BSB, Beban Personalia, Beban Bagi Hasil, dan Total Pembiayaan berpengaruh signifikan terhadap tingkat efisiensi.

4. Pada hubungan antara tingkat efisiensi dengan tingkat profitabilitas, diketahui BMI memiliki tingkat efisiensi biaya rendah dan profitabilitas yang cukup; pada BSM memiliki tingkat efisiensi biaya rendah dan profitabilitas yang tinggi; pada BMS memiliki tingkat efisiensi biaya yang cukup dan profitabilitas yang tinggi; pada BRIS memiliki tingkat efisiensi biaya rendah dan profitabilitas yang rendah; dan pada BSB memiliki tingkat efisiensi biaya rendah dan profitabilitas yang rendah. 
5. Ada berbagai strategi dalam meningkatkan efisiensi biaya dan strategi dalam menghadapi MEA pada bank syariah, di antaranya yaitu meningkatkan aset, DPK, memangkas biayabiaya yang tidak perlu, inovasi produk keuangan syariah, penurunan gaji para Direksi, menempatkan dana yang ada pada portofolio yang menguntungkan.

Kesimpulan di atas memberikan berbagai implikasi sebagaimana diulas sebelumnya, yang dapat dirangkum sebagai saran-saran sebagai berikut:

1. Pihak manajemen bank, diharapkan untuk terus meningkatkan tingkat efisiensi biayadengan mengurangi biaya-biaya yang tidak efektif. Profitabilitas juga harus dioptimalkan dengan adanya penempatan dana-dana produktif agar dana yang ada dapat menghasilkan profit yang lebih besar.

2. Bagi Bank Indonesia, perlu dibuatkan kriteria nilai tingkat efisiensi yang baku. Agar terjadi pemahaman yang sama terhadap nilai tingkat efisiensi dari suatu bank.

3. Bagi peneliti selanjutnya, penentuan variabel-variabel independen agar lebih banyak dan divariasikan agar model yang diformulasikan lebih baik lagi. Selain itu, perlu dikaitkan dengan tingkat likuiditas BUS. Serta dianalisis dengan analisis tambahan yaitu analisis Risk Base. 


\section{DAFTAR PUSTAKA}

Aigner, D. Lovell, CAK. dan Schmidt, P.1977. Formulation and Estimation of Stochastic Frontier Production Function Models. Journal of Econometrics 6 (21).

Ana, L. 2012. Efisiensi Bank-Bank Merger dan Akuisisi di Indonesia [Tesis]. Bogor (ID): Institut Pertanian Bogor.

[BI] Bank Indonesia. 2013. Statistik Perbankan Syariah. [diunduh 2013 Oktober 15]. Tersedia pada http//:www.bi.go.id.

[BI] Bank Indonesia. 2014. Outlook Perbankan Syariah 2014. [diunduh 2013 Oktober 15]. Tersedia pada http//:www.bi.go.id.

Berger, AN. dan Humphrey, DB. 1992. Measurement and Efficiency Issues in Commercial Banking. University of Chicago Press.

Bisnis. 2014. Bank Mega Syariah Raup Laba Rp209 Miliar. [diunduh 2015 Januari 2]. Tersedia pada: http://finansial.bisnis.com/read/20140203/90/200831/bank-mega-syariah-raup-labarp209-miliar.

Farrell, MJ. 1957. The Measurement of Productive Efficiency. Journal of the Royal Statistical Society, Series A (General), Vol.120, No.3 (253).

Firdaus, MF. 2013. Efisiensi Bank Umum Syariah Menggunakan Pendekatan Two-Stage Data Envelopment Analysis. Buletin Ekonomi Moneter dan Perbankan, Vol. 16 No.2, (150).

Hadad, MD. Santoso, W. Mardanugraha, E. dan Illyas, D. 2003. Analisis Efisiensi Industri Perbankan Indonesia: Penggunaan Metode Nonparametrik Data Envelopment Analysis (DEA). Jurnal Bank Indonesia.

Hadad, MD. Santoso, W. Mardanugraha, E. dan Illyas, D. 2003. Pendekatan Parametrik untuk Efisiensi Bank Syariah. Jurnal Bank Indonesia.

Hartono, E. Analisis Efisiensi Biaya Industri Perbankan Indonesia Dengan Menggunakan Metode Parametrik Stochastic Frontier Analysis (Studi Pada Perbankan yang Terdaftar di Bursa Efek Indonesia Periode 2004-2007) [Tesis]. Semarang (ID): Universitas Diponegoro.

Idroes, FN. dan Sugiarto. 2006. Manajemen Risiko Perbankan Dalam Konteks Kesepakatan Basel dan Peraturan Bank Indonesia. Yogyakarta (ID): Graha Ilmu.

Infobank News. 2013. BSM Ingin Dikenal Sebagai Bank Haji. [diunduh 2015 Januari 2]. Tersedia pada: http://www.infobanknews.com/2013/12/bsm-ingin-dikenal-sebagai-bank-haji/. 
Istianawati, H. 2014. Potensi Investasi dan Pengaruh Rasio Keuangan Terhadap Return Saham pada Sektor Pertambangan Kelompok Saham Pro Lingkungan Syariah [Tesis]. Bogor (ID): Institut Pertanian Bogor.

Kontan. 2014. 3 Faktor Penyebab Laba BRI Syariah Merosot 97\%. [diunduh 2015 Januari 2]. Tersedia pada: http://keuangan.kontan.co.id/news/3-faktor-penyebab-laba-bri-syariahmerosot-97.

Kusmargiani, IS. 2006. Analisis Efisiensi Operasional dan Efisiensi Profitabilitas Pada Bank yang Merger dan Akuisisi di Indonesia (Studi Pada Bank Setelah Rekapitalisasi dan Restrukturisasi Tahun 1999-2002) [Tesis]. Semarang (ID): Universitas Diponegoro.

Leibenstein, H. 1966. Allocative Efficiency vs. "X-Efficiency". The American Economic Review, Vol. 56, Issues 3.

Mester, LJ. 2003. Applying Efficiency Measurement Techniques to Central Banks." Working Paper No.03-13. Finance Department, The Wharton School, University of Pennsylvania.

Metrotv News. 2014. Gadai Emas BSM Naik 557\%. [diunduh 2015 Januari 2]. Tersedia pada: http://ekonomi.metrotvnews.com/read/2014/09/07/288373/gadai-emas-bsm-naik-557.

Mokhtar, HAS. Abdullah, N. dan Al-Habshi, SM. 2006. Efficiency of Islamic Banking in Malaysia, A Stochastic Frontier Approach. Journal of Economic Cooperation (27).

Muhari, S. dan Hosen, MN. 2013. Efficiency of the Sharia Rural Bank in Indonesia Lead to Modified CAMEL. Journal of Academic Research in economics and Management Sciences, Vol.2, No. 5.

Muhari, S. dan Hosen, MN. 2013. Analisis Tingkat Efisiensi BPRS di Indonesia dengan Menggunakan Data Envelopment Analysis (DEA) dan Hubungannya dengan CAMEL. Palembang (ID): Konferensi Riset Manajemen VII.

Putri, VR. dan Lukviarman, N. 2008. Pengukuran Kinerja Bank Komersial Dengan Pendekatan Efisiensi, Studi Terhadap Perbankan Go-Public di Indonesia. Journal JAAI, Volume 12 (1).

Republika Online. 2015. Laba Bersih untuk Cadangan, Muamalat tak Bagikan Deviden. [diunduh 2015 Januari 2]. Tersedia pada: http://www.republika.co.id/berita/ekonomi/syariahekonomi/14/07/10/n8hpy2-laba-bersih-untuk-cadangan-muamalat-tak-bagikan-dividen.

Suseno, P. 2008. Analisis Efisiensi dan Skala Ekonomi Pada Industri Perbankan Syariah di Indonesia. Journal of Islamic and Economics, Volume 2 (1).

Sutawijaya, A. Lestari. dan Etty, P. 2009. Efisiensi Teknik Perbankan Indonesia Pasca Krisis Ekonomi: Sebuah Studi Empiris Penerapan Model DEA. Jurnal Ekonomi Pembangunan, Volume 10 (1). 
Undang-Undang No. 21 Tahun 2008 tentang Perbankan Syariah.

Yaumidin, UK. 2007. Efficiency in Islamic Banking: A Non-Parametric Approach. Buletin Ekonomi Moneter dan Perbankan, Volume 9 (4).

Yudistira, D. 2004. Efficiency in Islamic Banking: An Emprical Analysis of Eighteen Banks. Islamic Economic Studies, Vol. 12 (1). 